\title{
Erratum to: 'Tocolysis for inhibiting preterm birth in extremely preterm birth, multiple gestations and in growth-restricted fetuses: a systematic review and meta-analysis'
}

Celine Miyazaki ${ }^{1}$, Ralf Moreno Garcia ${ }^{1}$, Erika Ota ${ }^{1 *}$, Toshiyuki Swa ${ }^{2}$, Olufemi T. Oladapo ${ }^{3}$ and Rintaro Mori ${ }^{1}$

Unfortunately, the original version of this article [1] contained an error. The spelling of the author [Ralfh Moreno Garcia] name was incorrect. This has been corrected above and also included correctly below:

Ralf Moreno Garcia

\section{Author details}

'Department of Health Policy, National Center for Child Health and Development, Tokyo, Japan. ${ }^{2}$ Graduate School of Human Sciences, Osaka University, Osaka, Japan. ${ }^{3}$ Department of Reproductive Health and Research, World Health Organization, Geneva, Switzerland.

Published online: 09 March 2016

\section{Reference}

1. Miyazaki C, Garcia RM, Ota E, Swa T, Oladapo OT, Mori R. Tocolysis for inhibiting preterm birth in extremely preterm birth, multiple gestations and in growth-restricted fetuses: a systematic review and meta-analysis reproductive health. Reprod Health. 2015;13:4.

\footnotetext{
*Correspondence: ota-e@ncchd.go.jp

'Department of Health Policy, National Center for Child Health and

Development, Tokyo, Japan
}

Submit your next manuscript to BioMed Central and we will help you at every step:

- We accept pre-submission inquiries

- Our selector tool helps you to find the most relevant journal

- We provide round the clock customer support

- Convenient online submission

- Thorough peer review

- Inclusion in PubMed and all major indexing services

- Maximum visibility for your research

Submit your manuscript at www.biomedcentral.com/submit

\section{() Biomed Central}

